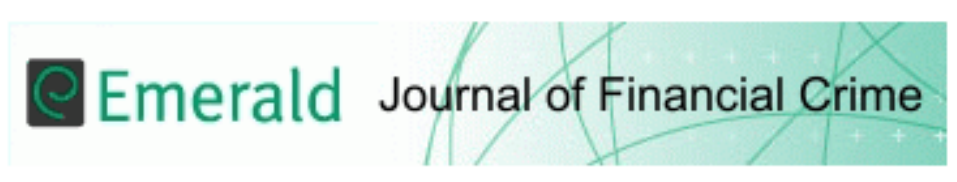

\title{
Political connections and corporate social responsibility reporting in Portugal
}

\begin{tabular}{|r|l|}
\hline Journal: & Journal of Financial Crime \\
\hline Manuscript ID & JFC-10-2018-0111 \\
\hline Manuscript Type: & Scholarly Article \\
\hline Keywords: & CSR reporting, Portugal, Political connections \\
\hline \multicolumn{2}{|l}{} \\
\hline
\end{tabular}




\title{
Political connections and corporate social responsibility reporting in Portugal
}

\begin{abstract}
Purpose: This paper examines the relation between firms' political connections and corporate social responsibility (CSR) reporting in Portugal. We argue that in settings where the existence of political connections are viewed as damaging collective interests of stakeholders, political connected firms can deal with legitimacy issues from such connections by resorting to CSR practices and the reporting thereof.

Methodology: Using archival data from a panel sample of 36 firms from Portugal between 2009 and 2012, we examine the relation between political connections and CSR reporting by way of regression analysis.

Findings: We find a positive relation between political connections and CSR reporting.

Originality: This study draws on legitimacy theory to highlight that CSR can be used to deal with stakeholder activism and vigilance pertaining to suspicion related to the existence of political connections.
\end{abstract}

Keywords: Corporate social responsibility reporting, political connections, Portugal 


\section{Introduction}

This study examines whether politically connected companies are more likely to present higher levels of corporate social responsibility (CSR) reporting in Portugal. In particular, it examines the relation between the presence of politicians on firms' boards of directors and their CSR reporting.

The notion of corporate political connections (CPC) pertains to the establishment by firms of relationships to political power. They are many times seen as obscure relations between politicians and firms, in which both agents engage to obtain private gains. Bianchi and Viana (2014) refer to direct and indirect political connections. The former type pertains to cases in which a firm's top executives or largest shareholders are or have been politicians, civil servants, members of parliament or close to political power (including though kin relationships with politicians). The latter type of corporate connections includes things such as lobbying activities, funding of political parties, politicians or political campaigns. Given that corporate political funding is not allowed by law in Portugal, our study focuses on the first type of CPC.

The concept of CSR depicts the imbricated character of business and society and deals especially (albeit not only) with responsibilities attributable to firms regarding the detrimental impacts of their activities on the society and the environment. It implies the consideration by firms of "the impact of their actions on stakeholders in society, while simultaneously contributing to global sustainability" (Sarkar and Searcy, 2016, p. 1433). CSR reporting has to do with the communication of information about companies' engagement with CSR. This type of communication is usually undertaken in companies' annual reports, websites, or in separate reports, and, besides financial information, involves 
topics such as climate change abatement, employee relations, human rights, philanthropy, product liability, and corporate governance (Montecchia et al., 2016).

There is a wealth of studies analysing how firms may benefit from political connections (Fisman, 2001; Khwaja and Mian, 2005; Faccio et al., 2006; Faccio, 2006, 2010; Faccio and Parsley, 2009; Claessens et al., 2008; Goldman et al. 2009, 2013; Boubakri et al., 2012; Correira, 2014; Gray et al., 2016). The case is not the same regarding the study of the relation between political connections and CSR or the reporting thereof. What is more, the vast majority of the existing studies on the relation between CPC and CSR and the reporting thereof focus on China (Marquis and Qian, 2014; Cheng et al., 2017; Li and Zhang, 2010; Gao, 2011; Gu et al., 2013; Li et al., 2015; Lin et al., 2015; Huang and Zhao, 2016). Only Rahman and Ismail (2016) escape this trend and study the relation between CSR reporting in Malaysia. The majority of these studies examine how CPC relate to corporate philanthropy (Li and Zhang, 2010; Gao, 2011; Gu et al., 2013; Li et al., 2015; Lin et al., 2015; Huang and Zhao, 2016). A few more recent studies explore the relation between CPC and CSR reporting (Marquis and Qian, 2014; Cheng et al., 2017; Muttakin et al., 2018; Rahman and Ismail, 2016).

Studies on CPC tend to focus on developing countries, where the benefits of political connections may be more substantial (Li et al., 2016). The vast majority of these studies focus on China, where "the government dominates the resource allocation and sets national macrocontrol policies" ( $\mathrm{Li}$ et al., 2016, p. 150). There is a relative wealth of studies on CPC including the USA in the sample used (Boubakri et al., 2012; Faccio, 2006, 2010) or focusing on this country (Goldman et al., 2009, 2013; Houston and Ferris, 2015). There are few studies on CPC and their value to firms on developed countries other than the US (Niessen and Ruenzi, 2009; Amore and Bennedsen, 2013; Gray et al., 2016). All the studies examining the 
relation between CPC and CSR and the reporting thereof focus on developing countries: Malaysia in the case of Rahman and Ismail (2016), Bangladesh in the case of Muttakin et al. (2018), and China in the case of the remaining studies. As far as we are aware, our study is the first to explore this topic in a developed country setting, that of Portugal.

Portugal presents a good setting in which to study the relation between firms' political connections and their CSR communication. The presence of politicians and prominent political figures on corporate boards is a pervasive situation in listed companies. Costa et al. (2010), Louçã et al. (2014) and Mulcahy (2015) present evidence of a high degree of promiscuity between political and economic power in Portugal. Bianchi and Viana (2014) found that the majority of Portuguese listed companies have political connections and some politicians are connected to several companies. 53 percent of the Portuguese respondents to the Transparency International's 2013 Global Corruption Barometer consider that their government is "run by a few big interests looking out for themselves" (Transparency International, 2013). European Commission’s Flash Eurobarometer 428, on Businesses’ Attitudes Towards Corruption in the EU, indicates that 66 percent of the Portuguese businesses surveyed consider that political connections are the only way to succeed in business (European Commission, 2015).

This study aims at contributing to the literature on the relation between CPC and CSR. Grounded on legitimacy theory, according to which CSR is seen as an instrument that can be used to achieve legitimacy, we expect that firms presenting higher levels of political connections are more likely to report on their engagement with CSR as a way of garnering support from stakeholders.

The rest of this paper is organized as follows. The next section is devoted to prior literature. Section 3 presents the theoretical background and hypothesis development. Section 


\begin{abstract}
4 presents the methodology used. Section 5 presents the main findings. Section 6 offers a discussion of results and some concluding remarks.
\end{abstract}

\title{
2. Prior literature
}

The literature exploring the relation between CPC and corporate transparency is scant and the evidence it provides on such relation is mixed (e.g., Chaney et al., 2011; Guedhami et al., 2014). Boubakri et al. (2012, p. 544) argue that given the predominantly political background (rather than professional) of politically connected executives, "their incentives tend to be driven by political considerations." These authors offer as an illustration of their argument the evidence provided by Leuz and Oberholzer-Gee (2006), who found politically connected firms from Indonesia to be less likely to have publicly traded debt or equity securities abroad, which may be explained by the increased difficulty that owners may have in extract private benefits of control in the wake of the increased scrutiny and transparency resulting from cross-listing.

Not many studies have examined how a firm's corporate connections are related to its reporting practices. Some of these studies explore the case of financial reporting (Chaney et al., 2011; Batta et al., 2014; Guedhami et al., 2014; Harymawan and Nowland, 2016). Other studies explore how political connections are associated with non-financial reporting (Cheng et al., 2017; Rahman and Ismail, 2016; Al-Hadi et al., 2016; Chen et al., 2017). We focus on the latter type of studies in view of their relevance to our study of the relation between CPC and CSR reporting.

Chen et al. (2017, p. 96) argue that: “(a) firms that enjoy political patronage are less likely to provide informative disclosures, given the high costs (relative to benefits) of 
disclosure; (b) loss of political patronage in a highly publicized scandal forces them to increase their disclosures to avoid the increased risk and costs of public scrutiny or political/regulatory sanctions." Using a sample of 65 Shanghai-listed companies involved in the Shanghai Pension corruption scandal, which they considered as "politically connected firms", they analysed whether their two basic arguments would hold. Their findings suggest that connected firms presented lower levels of disclosure than those of benchmark firms prior to the scandal, and that they significantly increased their voluntary disclosures in the wake of the loss of their political patrons. Chen et al. (2017, p. 92) concluded that higher levels of voluntary disclosure after the scandal could be deemed as a response "to the heightened risk and potential costs of regulatory and public scrutiny in the wake of a major event involving high political and public sensitivity". Their findings indicate a negative relation between political connections and voluntary disclosure. They interpret this findings as o the extent that politically connected firms are shielded from market discipline due to their undue advantages derived from political connectedness, and to the extent that such firms are not necessarily more efficient and may be more opaque, severing political ties and reinforcing market discipline can improve resource allocation, corporate transparency, and investor protection." (pp. 115-116)

Al-Hadi et al. (2016) analysed the relation between the presence of ruling family members on corporate boards and market risk disclosures in the annual reports of listed financial firms from the Gulf Cooperation Council countries (Oman, Bahrain, Kuwait, Qatar, the Kingdom of Saudi Arabia, and the United Arab Emirates). Their findings revealed that the extent and quality of market risk disclosures are significantly lower for firms that are politically connected, that is, have in their boards ruling family members. 
The vast majority of extant studies on the relation between CPC and CSR focus on China (Cheng et al., 2017; Li and Zhang, 2010; Gao, 2011; Gu et al., 2013; Li et al., 2015; Lin et al., 2015; Huang and Zhao, 2016). Only Rahman and Ismail (2016) escape this trend and study the relation between CSR reporting in Malaysia. The majority of these studies examine how CPC relate to corporate philanthropy (Li and Zhang, 2010; Gao, 2011; Gu et al., 2013; Li et al., 2015; Lin et al., 2015; Huang and Zhao, 2016). A few more recent studies explore the relation between CPC and CSR reporting (Cheng et al., 2017; Rahman and Ismail, 2016).

Using a sample of listed Chinese companies from heavily polluted industries Cheng et al. (2017) found that CPC are positively related with the quantity of environmental information disclosure, but not with its quality. Companies seem to choose to focus their environmental reporting on "soft" information (such as environmental governance policies, environmental objectives, and energy conservation initiatives), over "hard" information, which they avoid (such as negative pollutant emissions, pollution fines, and compensation information).

Rahman and Ismail (2016) used a sample of 300 non-financial listed Malaysian firms for the year 2013, and found that no significant relation exists between CSR reporting and politicians on the board of directors. However, they have found that the other proxy for political connections they used, government ownership, was positively and significantly related with such reporting.

Muttakin et al. (2018) used a sample of 936 firm-year observations pertaining to companies listed on the Dhaka Stock Exchange from Bangladesh regarding the period 20052013 to examine the voluntary CSR disclosures. Their results suggest that CPC are negatively associated with CSR disclosures. 
All these studies have been conducted in a developing country setting, where its characteristics and consequences, as well as the perceptions regarding it, are very specific, in particular in China. For example, in China the government is an important initiator, stakeholder, and audience of CSR (Zhang et al., 2016). The same is not the case in developed countries, where CPC are viewed with extreme suspicion.

\section{Theoretical framework and hypothesis}

While acknowledging the "noteworthy proliferation of theoretical perspectives", Montechia et al. (2016, p. 44) suggest that the quest for legitimation is "commonly embraced by scholars as the primary purpose that encourages and motivates companies to disclose" CSR information. It is thus not surprising that legitimacy theory is among the main theories used in CSR reporting research (Michelon et al., 2016). Legitimacy theory is based on the idea that to ensure that they continue to operate successfully organization must behave in a manner which is coherent with what is deemed as socially acceptable behaviour by society. Moreover, as stated by Montechia et al. (2016, p. 44), it "is grounded on the assumption that managers will adopt strategies to demonstrate that the organization is attempting to comply with society's expectations."

Suchman (1995, p. 574) provided one of the most cited definitions of legitimacy: "legitimacy is a generalized perception or assumption that the actions of an entity are desirable, proper, or appropriate within some socially constructed system of norms, values, beliefs, and definitions." Suchman already underlined the importance of the disclosure of information to legitimacy management when acknowledging that it "rests heavily on communication" (Suchman, 1995, p. 586). Later legitimacy theory proponents emphasize 
even more this aspect, and assert that the perspective put forward by legitimacy theory "highlights the strategic importance (and power) of corporate disclosures" (Deegan, 2002, p. 296).

Legitimacy theory proponents put forward the idea corporate disclosure of relevant information is triggered or at least strongly influenced by numerous economic, environmental, social and political factors, and it is an important tool in the legitimation of a company's actions (Kent and Zunker, 2013). Corporate disclosure policies are considered to “represent a method for management to influence external perceptions about their company's activities" (Kent and Zunker, 2013, p. 1077).

According to such a lens of analysis, companies are supposed to undertake activities that are consistent with social values and to provide information to society's members that such activities are in consonance with the values held by society. In cases where a company managers view the values implied by their company's activities as nonconforming with those held as important by society, remedial actions on the part of the company are required (Deegan, 2002). To be effective, these actions "must be accompanied by disclosure" (Deegan, 2002, p. 296).

Numerous studies that adopt legitimacy theory as theoretical framework examine how a company or companies operating in the same industry react to events that are considered as threats to their legitimacy through CSR reporting (Brown \& Deegan, 1998; Cho, 2009; Coetzee \& van Staden, 2011; Deegan, 2002; Deegan and Rankin, 1996; Deegan et al., 2002; Milne \& Patten, 2002; Noronha, Leung, \& Lei, 2015; Patten, 1991; Patten, 1992; Vourvachis, Woodward, Woodward, \& Patten, 2016; Watson, 2011). The overall conclusion is that companies change CSR reporting practices following major events that affect the company and the industry in which it operates. 
Based on legitimacy theory, the argument in this study is that in contexts in which CPC are viewed with great suspicion the relation between CPC and CSR is positive. This argument relates CSR and the reporting thereof with the need for a company with political connections to show that in spite of having such connections it is a company that operates in accordance with society's expectations.

In view of the above, we hypothesize that politically connected companies disclose higher levels of CSR information than their counterparts.

\section{Methodology}

Our sample includes all non-financial firms listed on Euronext Lisbon between 2009 and 2012. It only includes firms under the Portuguese law. Given their specificity and the fact that their reporting period does not match the calendar year as is the case regarding the other firms, football firms were excluded from the sample. The final sample consists of 144 firm-year observations, regarding 36 firms. Table 3 includes information on the distribution of the companies by industry.

To measure the dependent variable (CSR reporting), we used the total number of pages (Cowen et al., 1987; Deegan and Rankin, 1996) devoted to CSR information both in annual reports and in CSR/Sustainability reports.

To measure CPC, the names of the Officials of General Meeting of Shareholders (GMS) and of the elements that compose the Board of Directors (BD) and the Supervisory Boards (SB) were hand collected using the firms' annual corporate governance reports for the period 2009-2012. Moreover, given that corporate governance reports usually include, in attachment, the board members' curricula, it was possible to identify some political 
connections. Two other sources of information were consulted: (1) a list of Portuguese political governors of the last 36 years who held a management position in the largest firms ${ }^{1}$, developed by Costa el al. (2010); and (2) Google web search, where we have examined the political activity of each individual. Names that matched members of parliament or government were cross-checked using the official websites of Portuguese Government and Portuguese Parliament. In this study CPC is a binary variable that assumes the value 1 if at least one element of its management and supervisory bodies (Board of Directors and Supervisory Board) is a current or a former government member or a member of the parliament, and 0 otherwise.

We also include several control variables to capture other factors that are likely to influence CSR reporting. To measure these variables, both financial and non-financial data were collected. The first type of data (profitability, market capitalization, and leverage) were gathered mainly from OSIRIS (Bureau van Dijk) database. The latter type of data (age, industrial affiliation, listing status, state-ownership, and foreign ownership) were handcollected and supplemented by information reported in the OSIRIS database.

We used multiple linear regression to test the relationships between the dependent and the independent variables. The model used is as follows:

$$
\begin{aligned}
& \text { CSRep } i=\beta_{0}+\beta_{1_{i}} \text { CPC }+\beta_{2_{i}} \text { PSI2O }+\beta_{3_{i}} \text { StOwn }+\beta_{4_{i}} \text { ForOwn }+\beta_{5_{i}} \text { LogMktCap }+\beta_{6_{i}} \text { ROA } \\
& +\beta_{7_{i}} \text { Leverage }+\beta_{8_{i}} \text { Age }+\beta_{9_{i}} \text { Industry }
\end{aligned}
$$

where:

CSRep Total number of pages devoted to CSR information

CPC Dummy variable which assumes the value 1 if the firm is a politically connected and 0 otherwise StOwn Percentage of ordinary shares owned by state ForOwn Percentage of ordinary shares owned by foreign investors. MktCap Natural logarithm of market capitalization

\footnotetext{
${ }^{1}$ This list is the result of a research that focused on ministers and secretaries of state from strategic sectors of the economy, finance, public works, employment and planning.
} 
$\begin{array}{ll}\text { ROA } & \text { Ratio of operating income to total assets } \\ \text { Leverage } & \text { Long term debt divided by total assets } \\ \text { Age } & \text { Number of years since constitution } \\ \text { Industry } & \text { Industry-type indicator variable }\end{array}$

\section{Results}

\subsection{Descriptive analysis}

Descriptive statistics for the continuous and categorical variables are presented in Table 1. Our independent variable (CSRep) has an average value of 28.69, which suggests a relatively low level of disclosure when compared to the maximum of 186 . The mean value for the variables MktCap and ROA are, respectively, 12.04 and 3.78. The average value for the variable leverage is 26.18 and the mean value of the companies' age is 40.94. Regarding StOwn and ForOwn, their mean values are, respectively, 4.27 and 17.83.

In what concerns political connections, during the period 2009-2012 we have identified 76 firm-year observations, pertaining to 29 companies with political connections. These firms have employed a former or current politician in at least one year. 48 firm-year observations (22 firms) are from the sector Industrials, and the sectors consumer goods and consumer services and 4 contribute each with 24 firm-year observations (6 firms each).

Table 1 about here

Table 2 provides the Pearson correlation matrix for continuous independent variables. As shown in the table, the Pearson correlation coefficients between variables are not high, 
meaning that multicollinearity is not likely to be a problem. ${ }^{2}$ The highest correlation coefficients regarding the variable CSRep pertain to its relations to the variables MktCap, ForOwn and ROA, albeit all below 0.4 (at $p<.01$ ). The relation between ForOwn and MktCap is little over 0.5 (at $p<.01$ ).

Table 2 about here

\subsection{Regression analysis}

Results of the regression analysis are provided in Table 3 . The adjusted $\mathrm{R}^{2}$ suggests that approximately $26 \%$ of the variation in CSR reporting scores between the companies can be explained by the independent variables included in the regression model.

Table 3 about here

Our findings provide support for the hypothesis developed above pertaining to the relation between CPC and CSR reporting. The estimated coefficient for the variable CPC is positive and statistically significant at the $5 \%$ level. ${ }^{3}$ Besides CPC, the variables MktCap, ForOwn and Leverage are statistically significant at the $10 \%$ level. Relative to their

2 As a rule-of-thumb, one may consider multicollinearity as harmful when it exceeds 0.8 (Gujarati, 2004, p. 359).

${ }^{3}$ We feel very comfortable in considering that this result as significant in view of the warnings regarding perils of strict adherence to particular thresholds (Wasserstein and Lazar, 2016). 
counterparts from companies from Telecommunications, present significantly lower levels of CSR reporting.

\section{Discussion and concluding remarks}

This study examines the relation between firms' political connections and their communication of information on the social responsibility practices in which they engage in a developed country setting. According to the widespread view of CPC as something detrimental to society, they can be viewed as having a negative relation to CSR in the sense of being a socially irresponsible practice that is associated with distortions of competition and of democratic representation. Notwithstanding, CPC are also likely to be positively associated to socially responsible practices. The argument adduced in this study in support of the expectation of a positive relation between CPC and CSR is based on legitimacy theory. In a developed country setting, in which the existence of political connections is mostly viewed as damaging collective interests of stakeholders, firms presenting high levels of political connections are expected to deal with stakeholder activism and vigilance by resorting to CSR practices and the reporting thereof.

The managers of a company with political connections are likely to feel the need to show that in spite of having such connections it is a company that operates in accordance with society's expectations, and this may be achieved through enhanced CSR reporting. Hence, our expectation was that politically connected companies would disclose higher levels of CSR information than their counterparts.

Results suggest that in Portugal companies with political connections are more likely to present higher levels of CSR reporting than their non-connected counterparts. They are 
congruous with the arguments presented in support of the hypothesis developed regarding the relation between $\mathrm{CPC}$ and CSR reporting. Based on legitimacy theory, we suggested that politically connected firms would have to deal with significant reputation concerns that could be tantamount to legitimacy problems and CSR reporting could be seen as a strategy established to garner the support stakeholders and alleviate legitimacy threats.

The results of the examination reported in this paper are in line with those of the studies that use legitimacy theory as a lens of analysis of the way in which legitimacy threatening events impact on the social exposure of an industry and lead to the usage of CSR communication to deal with it (Patten, 1992; Coetzee and van Staden, 2011; Watson, 2011; Noronha et al., 2015). They are also consistent with the findings of the plethora of empirical studies on CSR reporting that, grounded on legitimacy theory, report evidence that a company's higher public visibility is positively related to CSR reporting (Branco and Rodrigues, 2006; Cho, 2009; Brown and Deegan, 1998; Deegan, 2002; Milne and Patten, 2002; Patten, 1991). Companies with political connections do seem to disclose a more CSR information than their counterparts.

This paper contributes to the literature in two ways. First, by providing data on the relation between CSR reporting and CPC. Second, by analysing this relation grounded on legitimacy theory, which enabled us to develop a testable hypothesis regarding such relation. We extend legitimacy theory to the examination of a legitimacy concern that may by specific to a certain national or regional context.

The more obvious limitations of our study include the small size of the sample and being a single country study, which precludes the examination of the possible contextual effects on the relation analysed. Future research may address these limitations. Possible extensions to this study include the use of a larger sample of Portuguese companies, and/or 
the use of a cross-country sample. As far as we are aware, this is the first study examining the relation between CPC and CSR in developed countries. Future studies should extend the theoretical lens of analysis used in this study through the incorporation of insights about cultural factors influencing the relation between CPC and CSR using the extended framework on a cross-country study. In addition to the development of cross-country studies, which usually use relatively small national subsamples, it would be important to develop more indepth single-country studies.

\section{References}

Al-Hadi, A. K., Taylor, G. and Al-Yahyaee, K. H. (2016), "Ruling Family Political Connections and Risk Reporting”, The International Journal of Accounting, Vol. 51, pp. 504-524.

Amore, M. and Bennedsen, M. (2013), "The value of local political connections in a lowcorruption environment", Journal of Financial Economics, Vol. 110, 387-402.

Batta, G., Heredia, R. S. and Weidenmier, M. (2014), "Political Connections and Accounting Quality under High Expropriation Risk", European Accounting Review, Vol. 23 No. 4, pp. 485-517.

Bianchi, M. T. and Viana, R. C. (2014), "Political connections: evidence from listed companies in Portugal", International Journal of Economics and Accounting, Vol. 5 No. 1, pp. 75-95.

Boubakri, N., Guedhami, O., Mishra, D. and Saffar, W. (2012), "Political connections and the cost of equity", Journal of Corporate Finance, Vol. 18 No. 3, pp. 541-559.

Branco, M. C. and Rodrigues, L. L. (2006), "Communication of corporate social responsibility by Portuguese banks: A legitimacy theory perspective", Corporate Communications: An International Journal, Vol. 11 No. 3, pp. 232-248.

Brown, N. and Deegan, C. (1998), "The public disclosure of environmental performance information - A dual test of media agenda setting theory and legitimacy theory", Accounting and Business Research, Vol. 29 No. 1, pp. 21-41.

Chaney, P. K., Faccio, M. and Parsley, D. (2011), "The quality of accounting information in politically connected firms", Journal of Accounting and Economics, Vol. 51, pp. 5876. 
Chen, J. J., Cheng, X., Gong, S. X., and Tan, Y. (2017), "Implications of Political Patronage and Political Costs for Corporate Disclosure", Journal of Accounting, Auditing \& Finance, Vol. 32 No. 1, pp. 92-122.

Cheng, Z., Wang, F., Keung, C. and Bai, Y. (2017), "Will Corporate Political Connection Influence the Environmental Information Disclosure Level? Based on the Panel Data of A-Shares from Listed Companies in Shanghai Stock Market", Journal of Business Ethics, Vol. 143, pp. 209-221.

Cho, C. (2009), "Legitimation Strategies Used in Response to Environmental Disaster: A French Case Study of Total SA's Erika and AZF Incidents", European Accounting Review, Vol. 18 No. 1, pp. 33-62.

Claessens, S., Feijen, E. and Laeven, L. (2008), "Political connections and preferential access to finance: the role of campaign contributions", Journal of Financial Economics, Vol. 88 No. 3, pp. 554-580.

Coetzee, C. and Van Staden, C. J. (2011), "Disclosure Responses to Mining Accidents: South African Evidence", Accounting Forum, Vol. 35 No. 4, pp. 232--246.

Cooper, M.J., Gulen, H. and Ovtchinnikov, A.V. (2010), “Corporate political contributions and stock returns", Journal of Finance, Vol. 65 No. 2, pp. 687-724.

Correia, M. M. (2014), "Political connections and SEC enforcement", Journal of Accounting and Economics, Vol. 57 No. 2, pp. 241-262.

Costa, J., Fazenda, L., Honório, C., Louçã, F. and Rosas, F. (2010), Os Donos de Portugal Cem Anos de Poder Económico (1910-2010), Afrontamento.

Cowen S., Ferreri L. and Parker L.D. (1987), "The impact of corporate characteristics on social responsibility disclosure: a typology and frequency-based analysis", Accounting, Organizations and Society, Vol. 12 No. 2, pp. 111-122.

Deegan, C. (2002), "The legitimising effect of social and environmental disclosures - a theoretical foundation", Accounting, Auditing and Accountability Journal, Vol. 15 No. 3, pp. 282-311.

Deegan, C. and Rankin, M. (1996), "Do Australian Companies Report Environmental News Objectively? An Analysis of Environmental Disclosures by Firms Prosecuted Successfully by the Environmental Protection Authority", Accounting, Auditing \& Accountability Journal, Vol. 9 No. 2, pp. 50-67.

Deegan, C., Rankin, M. and Tobin, J. (2002), “An examination of the corporate social and environmental disclosures of BHP from 1983-1997: A test of legitimacy theory", Accounting, Auditing \& Accountability Journal, Vol. 15 No. 3, pp. 312-343.

European Commission (2015), Flash Eurobarometer 428 (Businesses' Attitudes Towards Corruption in the EU), TNS Political \& Social.

Faccio, M, (2006), "Politically connected firms”, American Economic Review, Vol. 96, pp. 369-385.

Faccio, M. (2010), "Differences between politically connected and non-connected firms: a cross country analysis”, Financial Management, Vol. 39, pp. 905-927. 
Faccio, M. and Parsley, D. C. (2009), "Sudden deaths: taking stock of geographic ties", Journal of Financial and Quantitative Analysis, Vol. 33 No. 3, pp. 683-718.

Faccio, M., Masulis, R. and McConnell, J. (2006), "Political connections and corporate bailouts", Journal of Finance, Vol. 61, pp. 2597-2635.

Fisman, R. (2001), "Estimating the Value of Political Connections", American Economic Review, Vol. 91 No. 4, pp. 1095-1102.

Gao, Y. (2011), "Philanthropic disaster relief giving as a response to institutional pressure: evidence from China”, Journal of Business Research, Vol. 64 No. 12, pp. 1377-1382.

Goldman, E., Rocholl, J. and So, J. (2009), "Do politically connected boards affect firm value?, Review of Financial Studies, Vol. 22, pp. 2331-2360.

Goldman, E., Rocholl, J. and So, J. (2013), "Politically connected boards of directors and the allocation of procurement contracts", Review of Finance, Vol. 17, pp. 1617-1648.

Gray, S., Harymawan, I. and Nowland, J. (2016), "Political and government connections on corporate boards in Australia: Good for business?", Australian Journal of Management, Vol. 41 No. 1, pp. 3-26.

Gu, H., Ryan, C., Bin, L. and Wei, G. (2013), "Political connections, guanxi and adoption of CSR policies in the Chinese hotel industry: Is there a link?" Tourism Management, Vol. 34, pp. 231-235.

Guedhami, O., Pittman, J. A. and Saffar, W. (2014), "Auditor choice in politically connected firms", Journal of Accounting Research, Vol. 52 No. 1, pp. 107-162.

Gujarati, D. N. (2004), Basic Econometrics, McGraw-Hill.

Harymawan, I. and Nowland, J. (2016), "Political connections and earnings quality", International Journal of Accounting \& Information Management, Vol. 24 No. 4, pp. 339-356.

Hillman, A. J. (2005), "Politicians on the board of directors: Do connections affect the bottom line?", Journal of Management, Vol. 31 No. 3, pp. 464-481.

Houston, R. and Ferris, S. (2015), "Does the revolving door swing both ways? The value of political connections to US firms", Managerial Finance, Vol. 41 No. 10, pp. 10021031.

Huang, H. and Zhao, Z. (2016), "The influence of political connection on corporate social responsibility - evidence from Listed private companies in China", International Journal of Corporate Social Responsibility, Vol. 1:9

Jia, M. and Zhang, Z. (2010), "Does political connection influence corporate philanthropy? Management World, Vol. 4, pp. 99-113.

Jia, M. and Zhang, Z. (2013), "The CEO's Representation of Demands and the Corporation's Response to External Pressures: Do Politically Affiliated Firms Donate More? Management and Organization Review, Vol. 9, pp. 87-114.

Kent, P. and Zunker, T. (2013), “Attaining legitimacy by employee information in annual reports", Accounting, Auditing and Accountability Journal, Vol. 26 No. 7, pp. 10721106. 
Khwaja, A. and Mian, A. (2005), "Do lenders favor politically connected firms? Rent provision in an emerging financial market", Quarterly Journal of Economics, Vol. 120 No. 4, pp. 1371-1411.

Lester, R. H., Hillman, A., Zardkoohi, A. and Cannella, A. A. (2008), "Former government officials as outside directors: The role of human and social capital", Academy of Management Journal, Vol. 51 No. 5, pp. 999-1013.

Leuz, C. and Oberholzer-Gee, F. (2006), "Political relationships, global financing, and corporate transparency: evidence from Indonesia", Journal of Financial Economics, Vol. 81 No. 2, pp. 411-439.

Li, D., Lin, H. and Yang, Y.-W. (2016), "Does the stakeholders - corporate social responsibility (CSR) relationship exist in emerging countries? Evidence from China", Social Responsibility Journal, Vol. 12 No. 1, pp. 147-166.

Li, S., Song, X. and Wu, H. (2015), "Political Connection, Ownership Structure, and Corporate Philanthropy in China: A Strategic-Political Perspective", Journal of Business Ethics, Vol. 129, pp. 399-411.

Lin, K. J., Tan, J., Zhao, L. and Karim, K. (2014), "In the name of charity: political connections and strategic corporate social responsibility in a transition economy", Journal of Corporate Finance, Vol. 32, pp. 327-346.

Louçã, F., Lopes, J.T. and Costa J. (2014), Os Burgueses: Quem são, Como Vivem, Como Mandam, Bertrand Editora.

Marquis, C. and Qian, C. (2014), "Corporate social responsibility reporting in China: Symbol or substance? Organization Science, Vol. 25 No. 1, pp. 127-148.

Michelon, G., Pilonato, S., Ricceri, F. and Roberts, R. W. (2016), "Behind camouflaging: traditional and innovative theoretical perspectives in social and environmental accounting research", Sustainability Accounting, Management and Policy Journal, Vol. 7 No. 1, pp. 2-25.

Milne, M. J. and Patten, D. M. (2002), “Securing organizational legitimacy: An experimental decision case examining the impact of environmental disclosures", Accounting, Auditing and Accountability Journal, Vol. 15 No. 3, pp. 372-405.

Montecchia, A., Giordano, F. and Grieco, C. (2016), "Communicating CSR: integrated approach or Selfie? Evidence from the Milan Stock Exchange", Journal of Cleaner Production, Vol. 136, pp. 42-52.

Mulcahy, S. (2015), Lobbying in Europe: Hidden Influence, Privileged Access, Transparency International.

Muttakin, M. B., Mihret, D. G. and Khan, A. (2018), “Corporate political connection and corporate social responsibility disclosures: A neo-pluralist hypothesis and empirical evidence", Accounting, Auditing \& Accountability Journal, Vol. 31, No. 2, pp. 725744.

Niessen A. and Ruenzi, S. (2009), "Political connectedness and firm performance: Evidence from Germany”, German Economic Review, Vol. 11, pp. 441-464. 
Noronha, C., Leung, T. C. H. and Lei, O. I. (2015), “Corporate social responsibility disclosure in Chinese railway companies. Corporate response after a major train accident", Sustainability Accounting, Management and Policy Journal, Vol. 6 No. 4, pp. $446-474$

Patten, D. M. (1991), “Exposure, legitimacy, and social disclosure”, Journal of Accounting and Public Policy, Vol. 10 No. 4, pp. 297-308.

Patten, D. M. (1992), "Intra-industry environmental disclosures in response to the Alaskan oil spill: a note on legitimacy theory", Accounting, Organizations and Society, Vol. 17 No. 5, pp. 471-475.

Qiu, D. and Xu, L. (2015), “TMT's political connections of private capital and corporate social responsibility performance - Based on Data of SME board", Soft Science, Vol. 1, pp. 11-14.

Rahman, I. M. A. and Ismail, K. N. I. K. (2016), "The effects of political connection on corporate social responsibility disclosure - evidence from listed companies in Malaysia”, International Journal of Business and Management Invention, Vol. 5 No. 2, pp. 16-21.

Rehbein, K. and Schuler, D. (2013), "Linking corporate community programs and political strategies: A resource based view”, Business \& Society, Vol. 54 No. 6, pp. 794-821.

Searcy, C. and Sarkar, S. (2016), "Zeitgeist or chameleon? A quantitative analysis of CSR definitions", Journal of Cleaner Production, Vol. 135, pp. 1423-1435.

Suchman, M. C. (1995), "Managing legitimacy: Strategic and institutional approaches", Academy of Management Review, Vol. 20 No. 3, pp. 571-610.

Sun, P., Mellahi, K. and Wright, M. (2012), “The contingent value of corporate political ties", Academy of Management Perspectives, Vol. 26 No. 3, pp. 68-82.

Transparency International (2013), Global Corruption Barometer 2013, Transparency International.

Vourvachis, P., Woodward, T., Woodward, D. G. and Patten, D. M. (2016), "CSR disclosure in response to major airline accidents: a legitimacy-based exploration", Sustainability Accounting, Management and Policy Journal, Vol. 7 No. 1, pp. 26-43.

Wang, H. and Qian, C. (2011), "Corporate philanthropy and corporate financial performance: The roles of stakeholder response and political access", Academy of Management Journal, Vol. 54, pp. 1159-1181.

Wasserstein, R. L. and Lazar, N. A. (2016), "The ASA's Statement on p-Values: Context, Process, and Purpose", The American Statistician, Vol. 70 No. 2, pp. 129-133.

Watson, S. (2011), "Conflict diamonds, legitimacy and media agenda: an examination of annual report disclosures”, Meditari Accountancy Research, Vol. 19 No. 1, pp. 94111.

Zhang, J., Marquis, C. and Qiao, K. (2016), “A Study of Corporate Charitable Donations of Chinese Firms”, Organization Science, Vol. 27 No. 5, pp. 1307-1324. 
Table 1 - Descriptive statistics Panel A: For continuous variables

Table 2 - Pearson correlation matrix for the continuous variables

\begin{tabular}{lrrrrrrr}
\hline & Tt & \multicolumn{1}{c}{ Age } & MktCap & Lev100 & ROA & \multicolumn{1}{l}{ StOwn } & \multicolumn{1}{l}{ ForOwn } \\
\hline CSRep & 1 & 0.010 & $0.486^{* *}$ & -0.033 & $.293^{* *}$ & 0.058 & $0.313^{* *}$ \\
Age & 0.010 & 1 & 0.026 & $-.205^{*}$ & -0.022 & -0.082 & -0.096 \\
MktCap & $0.486^{* *}$ & -0.001 & 1 & 0.133 & $0.485^{* *}$ & $0.230^{* *}$ & $0.588^{* *}$ \\
Leverage & -0.033 & $-.205^{*}$ & 0.127 & 1 & $-0.237^{* *}$ & $0.261^{* *}$ & -0.004 \\
ROA & $0.293^{* *}$ & -0.022 & $0.479^{* *}$ & $-.237^{* *}$ & 1 & 0.058 & $0.257^{* *}$ \\
StOwn & 0.058 & -0.082 & $0.223^{* *}$ & $.261^{* *}$ & 0.058 & 1 & 0.020 \\
ForOwn & $0.313^{* *}$ & -0.096 & $0.592^{* *}$ & -0.004 & $0.257^{* *}$ & 0.020 & 1 \\
\hline${ }^{* *}$. A Correlation is significant at the 0.01 level & & & & & \\
${ }^{*}$. Correlation is significant at the 0.05 level & & & & & \\
\hline
\end{tabular}

\begin{tabular}{|c|c|c|c|c|c|c|}
\hline \multicolumn{2}{|c|}{ Variable } & \multirow{2}{*}{$\begin{array}{l}\mathbf{N} \\
144\end{array}$} & \multirow{2}{*}{$\begin{array}{r}\text { Minimum } \\
0.00\end{array}$} & \multirow{2}{*}{$\frac{\text { Maximum }}{186.00}$} & \multirow{2}{*}{$\begin{array}{l}\text { Mean } \\
28.6944\end{array}$} & \multirow{2}{*}{$\begin{array}{c}\text { SD } \\
48.52500\end{array}$} \\
\hline $\begin{array}{l}\text { Dependent } \\
\text { variable }\end{array}$ & CSRep & & & & & \\
\hline \multirow{6}{*}{$\begin{array}{l}\text { Independent } \\
\text { variables }\end{array}$} & Lev & 144 & 0.00 & 67.86 & 26.1833 & 14.73524 \\
\hline & MktCap & 144 & 5.80 & 16.22 & 12.0352 & 2.17551 \\
\hline & ROA & 144 & -27.22 & 11.87 & 3.7798 & 5.11886 \\
\hline & Age & 144 & 2.00 & 220.00 & 40.9444 & 39.45783 \\
\hline & StOwn & 144 & 0.00 & 63.50 & 4.2706 & 11.16229 \\
\hline & ForOwn & 144 & 0.00 & 78.88 & 17.8273 & 20.52524 \\
\hline
\end{tabular}

Panel B: For categorical variables

\begin{tabular}{llr|r}
\hline & \multicolumn{1}{c|}{ Description } & N & \multicolumn{1}{c}{$\%$} \\
\hline CPC & No & 68 & $47.2 \%$ \\
\cline { 2 - 5 } & Yes & 76 & $52.8 \%$ \\
\cline { 2 - 5 } & Total & 144 & $100.0 \%$ \\
\hline Industry & Consumer goods & 24 & $16,7 \%$ \\
\cline { 2 - 5 } & Industrials & 48 & $33,3 \%$ \\
\cline { 2 - 5 } & Basic materials & 12 & $8,3 \%$ \\
\cline { 2 - 5 } & Consumer services & $16,7 \%$ \\
\cline { 2 - 5 } & Technology & $11,1 \%$ \\
\cline { 2 - 5 } & Telecommunications & 8 & $5,6 \%$ \\
\cline { 2 - 5 } & Utilities \& Oil and gas & 12 & $8,3 \%$ \\
\cline { 2 - 5 } & Total & 144 & $100,0 \%$ \\
\hline
\end{tabular}




\begin{tabular}{lrc}
\hline \multicolumn{3}{c}{ Table 3 - Regression results } \\
\hline Variables & B & Sig. \\
\hline Age & -0.102 & 0.238 \\
MktCap & 0.244 & 0.058 \\
Leverage & -0.140 & 0.112 \\
ROA & 0.083 & 0.373 \\
StOwn & -0.002 & 0.996 \\
ForOwn & 0.192 & 0.097 \\
CPC & 0.175 & 0.051 \\
Consumer goods & 0.055 & 0.708 \\
Industrials & 0.006 & 0.971 \\
Basic materials & -0.113 & 0.290 \\
Consumer services & -0.212 & 0.155 \\
Technology & -0.178 & 0.189 \\
Telecommunications & -0.273 & 0.006 \\
2009 & 0.027 & 0.773 \\
2010 & 0.038 & 0.673 \\
2011 & 0.017 & 0.849 \\
\hline Adj. $\mathrm{R}^{2}=0.257 ;$ & & \\
Durbin-Watson $=2.372$ & & \\
F = 3.914; $\mathrm{p}=0.000$ & & \\
\hline
\end{tabular}

